\title{
Obituaries
}

Obituaries should be submitted by email to Laura Pacey at I.pacey@nature.com.

All submitted obituaries should be 350 words maximum in length (apart from obituaries for past presidents of the BDA where the length should be $700-800$ words).

Content of the obituary is down to the individual author, and the approval of the family should be given for the obituary prior

to submission to the $B D J$.

\section{PETER DOUGLAS BIRD}

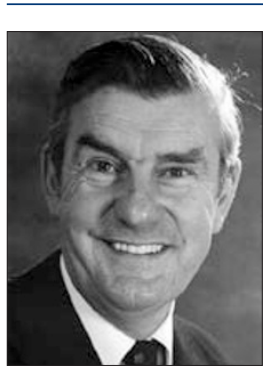

Shortly after leaving Caldy Grammar school, Peter joined the Royal Navy in the early stages of the War. He served as an officer in frigates on Atlantic escort duty. On

D-Day he was in command of six supply barges, landing on the Normandy beaches on $\mathrm{D}+1$.

On being demobbed he started as a dental student at Liverpool University in 1946, qualifying in 1952. A conscientious student he also rowed for the university in a coxed four, sailed at West Kirby and played golf at Caldy.

Disaster struck in 1954 when working as a resident SHO at Sefton General Hospital he contracted poliomyelitis and lost the use of his left arm. An unimaginable blow for a dentist.

Far seeing professors, Stones and Lawton, recognised the quality of the man and appointed him as lecturer and head of the expanding dental radiology department at Liverpool Dental Hospital. Peter made a reputation as an expert in his field and was admired as a lecturer.

In his personal life, disaster struck again in 1966 when his wife, Joan, suddenly died, entirely changing family life for him and his three young children. But in 1969 he married Ann and they happily added a daughter to the family.

He was a founder member of the British Society of Dental and Maxillofacial Radiology, as well as its secretary for seven years and president for two separate terms. For his help in setting up the International Association of Dentomaxillofacial Radiology he was made a vice-president in 1971.

He was admitted as an FDSRCS in 1984 and in that year was also awarded a diploma in dental radiology by the Royal College of Radiologists. He had the honour of being awarded life membership of the British Dental Association in 1988.

His life in retirement was made happy by nine grandchildren and one great grand-daughter. He travelled the country lecturing in aid of the Mary Rose Trust and later on the D-Day 'Overlord' tapestries and the historic Bayeux tapestries. With Ann he travelled to distant parts, usually by sea.

The sea was in his blood, but his immeasurable contribution was to dental radiology, and of course to his family.

John R. Davy

\section{VICTOR CECIL ERSKINE HARRINGTON}

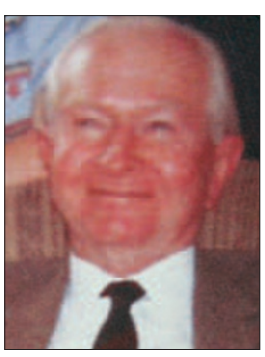

Victor Cecil Erskine Harrington passed away peacefully in Edinburgh on Friday 6 January 2012 at the age of 97. He was born on 17 May 1914 in Pietermaritzburg,

Kuazulu Natal, South Africa.

Victor's first four years were spent in Hlabesa, where his first language was Zulu. His independent spirit and respect for the people and their culture were shaped in those early days. Victor's father worked as a Zulu interpreter with Ghandi in the Durban courts and Victor remembered hearing Ghandi's lectures. Having attended Maritzburg College, in 1929 Victor sailed to England with his scout troop and in 1934 Victor headed for Edinburgh to study dentistry.

He was introduced to Bettine Ewart at a badminton club at the Princess Margaret Rose Hospital and they married on 3 May 1941, a union which lasted more than 50 years.

Victor had graduated in dentistry in June 1940 and joined the Royal Army Dental Corp. Arriving on the east coast of Africa, he spent the next four years serving in the deserts of Egypt and Syria, accruing a lifetime of stories. He proudly earned a number of medals for his service in the war. Victor then returned to Edinburgh where he set up in dental practice and worked there until retiring fully at the age of 70 . He was a well-respected and caring dental practitioner and also spent one day a week working in Saughton Prison. He was a past president of the South East of Scotland Branch of the BDA, served on the Lothian Health Board, was chairman of the Area Dental Committee and the GDP sub-committee and was a staunch supporter of the NHS.

He was an elder at St George's West Church for many years, a regular golfer in Edinburgh and Elie, and had a keen interest in cars.

Victor managed to live a full and independent life until he had a stroke in 2010. Victor was predeceased by his wife Bettine. He will be greatly missed by his four children, Joyce, Pamela, Michael and James and seven grandchildren. He instilled in all his offspring the principles of hard work and integrity. He was lucky enough to be able to speak a few words of Zulu with two African nurses in his nursing home, taking him full circle back to the Africa he knew as a child.

He will be fondly remembered by family, friends, colleagues and patients.

Michael E. Harrington and Pamela J. Milne 